\title{
PERANCANGAN DAN IMPLEMENTASI FUZZY INFERENCE SYSTEM (FIS) METODE TSUKAMOTO PADA PENENTUAN PENGHUNI ASRAMA
}

\author{
Aulia Akhrian Syahidi ${ }^{1}$, Fajerin Biabdillah ${ }^{2}$, Fitra A. Bachtiar ${ }^{3}$ \\ ${ }^{1,2,3}$ Magister Ilmu Komputer, Fakultas Ilmu Komputer, Universitas Brawijaya, Malang, Indonesia \\ Email: ${ }^{1}$ aakhriansyahidi@ student.ub.ac.id, ${ }^{2}$ fajerin@ student.ub.ac.id, ${ }^{3}$ fitra.bachtiar@ub.ac.id
}

(Naskah masuk: 11 November 2018, diterima untuk diterbitkan: 18 Desember 2018)

\begin{abstract}
Abstrak
Asrama mahasiswa dibangun sebagai tempat tinggal bagi sekelompok orang yang sedang manjalankan suatu tugas atau kegiatan yang sama. Untuk menentukan mahasiswa yang berhak menjadi penghuni asrama, maka dalam penelitian ini memberikan rekomendasi untuk menggunakan Metode Fuzzy Tsukamoto. Metode Fuzzy Tsukamoto dipilih karena ada beberapa kelebihan yang menonjol yaitu dapat mendefinisikan nilai yang kabur dari inputan penilaian, membangun, serta mengaplikasikan pengalaman-pengalaman dari pakar-pakar secara langsung sehingga tidak melalui proses pelatihan. Hasil analisis menyimpulkan bahwa: (1) Cara kerja Metode Fuzzy Tsukamoto memiliki tiga bagian yaitu: fuzzifikasi, inferensi fuzzy, dan defuzzifikasi, (2) Implementasi Metode Fuzzy Tsukamoto dapat menghitung penentuan penerimaan penghuni asrama mahasiswa pada studi kasus asrama mahasiswa putera "Negara Dipa Amuntai Malang", berdasarkan 19 data dengan membandingkan antara hasil penilaian pakar, hasil perhitungan Fuzzy Tsukamoto secara manual, dan hasil perhitungan Fuzzy Tsukamoto secara otomatis menggunakan sistem yang terprogram, telah diuji mempunyai tingkat akurasi keberhasilan sebesar $63,15 \%$ dengan predikat cukup.
\end{abstract}

Kata kunci: penentuan penghuni asrama, fuzzy tsukamoto, kecerdasan komputasional

\section{DESIGN AND IMPLEMENTATION OF FUZZY INFERENCE SYSTEM (FIS) TSUKAMOTO METHOD ON DETERMINATION OF DORMITORY RESIDENTS}

\begin{abstract}
Student dormitory is built as a residence for a group of people who are carrying out a task or the same activity. To determine the students who have the right to become boarders, in this study provide recommendations for using the Fuzzy Tsukamoto Method. Fuzzy Tsukamoto method was chosen because there are several prominent advantages that can define the value that is blurred from the assessment input, build, and apply experiences from experts directly so that they do not go through the training process. The results of the analysis concluded that: (1) The workings of the Fuzzy Tsukamoto Method have three parts: fuzzification, fuzzy inference, and defuzzification. (2) The implementation of the Fuzzy Tsukamoto method can calculate the determination of the admission of students in the student dormitory case study of male student dormitory "Negara Dipa Amuntai Malang," based on 19 data by comparing the results of the expert assessment, the results of Fuzzy Tsukamoto calculation manually, and the results of Fuzzy Tsukamoto calculations automatically using a programmed system, has been tested to have a success accuracy level of $63.15 \%$ with sufficient predicate.
\end{abstract}

Keywords: determination of dormitory residents, fuzzy tsukamoto, computational intelligence

\section{PENDAHULUAN}

Asrama adalah hunian bersama bagi pelajar yang dibangun dalam berbagai skala, mulai dari skala kecil (sampai 50 penghuni) hingga skala sangat besar dengan penyediaan lebih dari 200 kamar. Di berbagai negara maju, asrama ini telah dirancang dan dibangun dengan standar-standar khusus sesuai dengan jenjang usia penghuninya. Di negara-negara Eropa, asrama mahasiswa atau lebih dikenal dengan student housing banyak disedikan oleh pihak universitas untuk mewadahi kebutuhan hunian mahasiswa yang berasal dari luar kota, bahkan dari luar negeri. Di Indonesia keberadaan asrama mahasiswa mulai menjadi perhatian karena mampu menampung mahasiswa untuk tinggal dalam lingkungan kampus. Banyak kampus sekarang yang menyediakan fasilitas asrama mahasiswa (Khan, 2016). Selain itu dari pihak pemerintah daerah juga sudah mulai gencar membangun asrama mahasiswa bagi putera-puteri daerah yang kuliah di luar daerah 
domisilinya. Khususnya bagi mahasiswa yang berasal dari daerah Amuntai Kalimantan Selatan yang sedang berkuliah di luar daerah, maka tempat yang paling efektif untuk menjadi pilihan pertama adalah asrama mahasiswa yang dimiliki oleh Pemerintah Daerah Kabupaten Hulu Sungai Utara.

Amuntai merupakan Ibu Kota Kabupaten Hulu Sungai Utara yang terletak di Provinsi Kalimantan Selatan yang merupakan daerah mayoritas penduduknya bermata pencaharian sebagai petani, pedagang, peternak, dan lain-lain sebagainya. Seiring dengan perkembangan zaman, generasi masyarakat Amuntai sudah mulai banyak yang melanjutkan studi ke luar Kalimantan Selatan khususnya di Kota Malang, Jawa Timur, dengan jumlah mahasiswa aktif diperkirakan \pm 100 orang sampai tahun 2017 yang tersebar pada PTN maupun PTS di Kota Malang. Diantara sebaran perguruan tinggi di kota Malang yaitu Universitas Brawijaya, UM, UMM, ITN, UIN Maulana Malik Ibrahim, Universitas Islam Malang, dan lain-lain sebagainya.

Mahasiswa yang ingin menjadi penghuni asrama mahasiswa Amuntai di Malang harus melewati beberapa seleksi yang dilakukan oleh pihak pengelola asrama. Seleksi yang dilakukan berupa wawancara, kuesioner, dan sertifikat dengan sistem yang masih manual. Dengan meningkatnya jumah mahasiswa yang melanjutkan studi di Kota Malang dan banyak yang ingin menjadi penghuni asrama, tetapi daya tampung asrama yang disediakan sangat terbatas, itulah salah satu hal yang menyebabkan dilakukannya proses seleksi. Maka diusulkan perlu adanya sebuah sistem yang efektif dan efisien, agar dapat membantu pihak pengelola asrama dalam penentuan mahasiswa yang berhak menjadi penghuni asrama berdasarkan hasil dari seleksi yang dilakukan.

Untuk menentukan mahasiswa yang berhak menjadi penghuni asrama, maka pada penelitian ini merekomendasikan penggunaan Metode Fuzzy Tsukamoto dengan sistem berbasis web. Beberapa penelitian yang juga menggunakan Metode Fuzzy Tsukamoto yaitu (Indriana, 2014), (Bunga, 2014), (Rohayani, 2015), (Hadi, 2015), (Armanda, 2016), (Arifin 2016), (Mulyanto, 2016), (Parewe, 2016), (Afif, 2017), (Angin, 2017), (Kurnianingtyas, 2017), (Irmayanti, 2018), (Qur'ania, 2018), (Gerhana, 2018), dan (Jumadi, 2018). Namun, dari berbagai penelitian tersebut belum ada yang meneliti dengan studi kasus tentang penentuan penghuni asrama mahasiswa.

\section{METODE TSUKAMOTO}

Metode Fuzzy Tsukamoto dipilih karena ada beberapa kelebihan yang menonjol yaitu dapat mendefinisikan nilai yang kabur dari inputan penilaian, membangun, serta megaplikasikan pengalaman-pengalaman dari pakar-pakar secara langsung sehingga tidak melalui proses pelatihan. Pada metode ini pertama kali yang dilakukan yakni menentukan fungsi keanggotaan, menentukan rule, sehingga kategori diklasterisasi sesuai dengan rule yang diterapkan di masing-masing kelompok. Agar mahasiswa dapat menjadi penghuni asrama maka pada tahapan seleksi disesuaikan dengan beberapa hal yaitu berupa kriteria yang ditetapkan. Adapun kriteria yang akan dideklarasikan pada studi kasus ini yaitu nilai wawancara $(\mathrm{NW})$, nilai kuesioner (NK), dan nilai sertifikat (NS).

\section{HASIL DAN PEMBAHASAN}

\subsection{Perhitungan Manual}

Pada tahap perhitungan manual ini akan dilaksanakan oleh sistem serta rules yang ditetapkan oleh perhitungan Fuzzy Tsukamoto.

\section{Aturan-Aturan Inferensi Fuzzy}

Pada studi kasus ini terdapat tiga buah variabel input yaitu nilai wawancara, nilai kuesioner, dan nilai sertifikat dari mahasiswa itu sendiri, sedangkan untuk variabel output adalah status. Pada variabel input nilai wawancara memiliki tiga nilai linguistik yakni rendah, sedang, dan tinggi. Pada variabel input nilai kuesioner memiliki tiga nilai linguistik yaitu rendah, sedang, dan tinggi. Pada variabel input nilai sertifikat memiliki tiga nilai linguistik yakni rendah, sedang, dan tinggi. Sedangkan untuk variabel output yakni variabel status memiliki dua nilai linguistik yaitu tidak diterima dan diterima. Dari unit penalaran pada fuzzy inference, maka akan terbentuk aturan-aturan (rules), disajikan pada Tabel 1.

\begin{tabular}{ccccc}
\multicolumn{5}{c}{ Tabel 1. Aturan-Aturan yang Terbentuk pada Inferensi Fuzzy } \\
\hline No. & NW & NK & NS & Status \\
\hline 1 & Rendah & Rendah & Rendah & Tidak diterima \\
2 & Rendah & Rendah & Tinggi & Tidak diterima \\
3 & Rendah & Rendah & Sedang & Tidak diterima \\
4 & Rendah & Sedang & Rendah & Tidak diterima \\
5 & Rendah & Sedang & Tinggi & Tidak diterima \\
6 & Rendah & Sedang & Sedang & Tidak diterima \\
7 & Rendah & Tinggi & Rendah & Tidak diterima \\
8 & Rendah & Tinggi & Tinggi & Tidak diterima \\
9 & Rendah & Tinggi & Sedang & Tidak diterima \\
10 & Sedang & Tinggi & Rendah & Diterima \\
11 & Sedang & Tinggi & Tinggi & Diterima \\
12 & Sedang & Tinggi & Sedang & Diterima \\
13 & Sedang & Sedang & Rendah & Tidak diterima \\
14 & Sedang & Sedang & Tinggi & Diterima \\
15 & Sedang & Sedang & Sedang & Diterima \\
16 & Sedang & Rendah & Rendah & Tidak diterima \\
17 & Sedang & Rendah & Tinggi & Tidak diterima \\
18 & Sedang & Rendah & Sedang & Diterima \\
19 & Tinggi & Rendah & Rendah & Tidak diterima \\
20 & Tinggi & Rendah & Tinggi & Tidak diterima \\
21 & Tinggi & Rendah & Sedang & Tidak diterima \\
22 & Tinggi & Sedang & Rendah & Tidak diterima \\
23 & Tinggi & Sedang & Tinggi & Diterima \\
24 & Tinggi & Sedang & Sedang & Diterima \\
25 & Tinggi & Tinggi & Rendah & Diterima \\
26 & Tinggi & Tinggi & Tinggi & Diterima \\
27 & Tinggi & Tinggi & Sedang & Diterima \\
\hline & & & & \\
& & & & Tima \\
\hline
\end{tabular}




\section{Perhitungan Fuzzy Tsukamoto}

Perhitungan status menggunakan Fuzzy Tsukamoto jika akan melakukan penentuan penerimaan penghuni asrama mahasiswa terhadap salah satu mahasiswa dengan data input berikut, dimana sesuai dengan data yang sebenarnya pada studi kasus yakni:

Nama : M. Yanuar Syahrolly

Asal PT

: S2 Teknik Sipil/ITN Malang

Nilai Wawancara : 100

Nilai Kuesioner : 100

Nilai Sertifikat : 50

Langkah 1: Menentukan variabel yang terkait dalam proses yang akan ditentukan dan fungsi fuzzifikasi yang sesuai. Pada kasus ini, ada 4 variabel yang akan dimodelkan yaitu sebagai berikut:

Nilai Wawancara [x]: untuk variabel input nilai wawancara terdiri dari tiga nilai linguistik, yaitu Rendah, Sedang, dan Tinggi, sehingga dirumuskan membership function sebagai berikut:

$$
\begin{aligned}
& \mu \text { Nilai Wawancara Rendah }[\mathrm{x}] \quad\left\{\begin{array}{l}
1, x \leq 30 \\
30<x<40 \\
\mu \text { Nilai Wawancara Sedang }[\mathrm{x}]
\end{array}\right. \\
& \mu \text { Nilai Wawancara Tinggi }[\mathrm{x}] \quad\left\{\begin{array}{l}
30<\mathrm{x}<40 \\
1,40 \leq x \leq 70 \\
70<\mathrm{x}<80
\end{array}\right. \\
& \qquad \begin{array}{l}
1,80 \leq x \leq 100 \\
70<x<80
\end{array}
\end{aligned}
$$

Membership function nilai wawancara ditunjukkan pada Gambar 1.

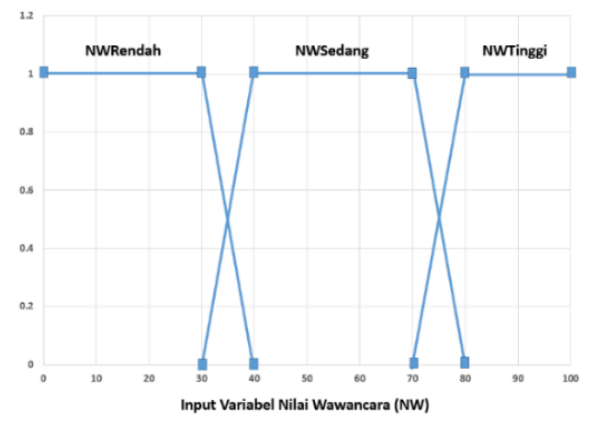

Gambar 1. Membership function Nilai Wawancara

Nilai Kuesioner [x]: untuk variabel input nilai kuesioner terdiri dari tigas nilai linguistik, yaitu Rendah, Sedang, dan Tinggi, untuk membership function dirumuskan sebagai berikut:

$$
\begin{aligned}
& \mu \text { Nilai Kuesioner Rendah }[\mathrm{x}] \\
& \mu \text { Nilai Kuesioner Sedang }[\mathrm{x}]
\end{aligned}\left\{\begin{array}{l}
\left\{\begin{array}{l}
1, x \leq 50 \\
50<x<60 \\
50<\mathrm{x}<60 \\
1,60 \leq x \leq 80 \\
80<\mathrm{x}<90
\end{array}\right. \\
\mu \text { Nilai Kuesioner Tinggi }[\mathrm{x}]
\end{array}\right.
$$

Membership function nilai kuesioner ditunjukkan pada Gambar 2.

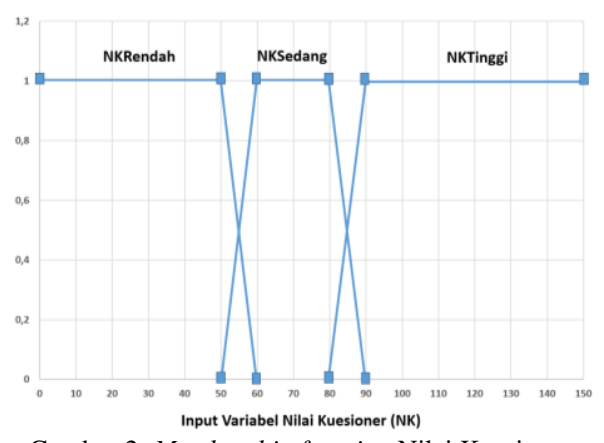

Gambar 2. Membership function Nilai Kuesioner

Nilai Sertifikat [x]: untuk variabel input nilai sertifikat terdiri dari tiga nilai linguistik, yakni Rendah, Sedang, dan Tinggi, untuk membership function dirumuskan sebagai berikut:

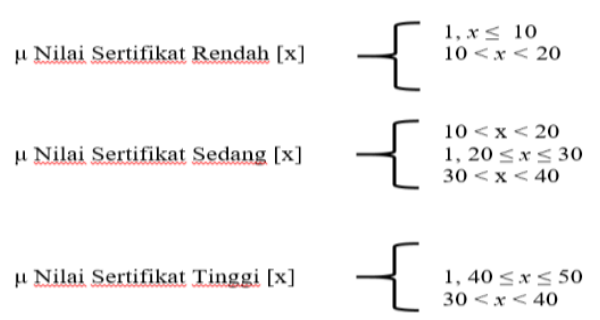

Membership function nilai sertifikat ditunjukkan pada Gambar 3.

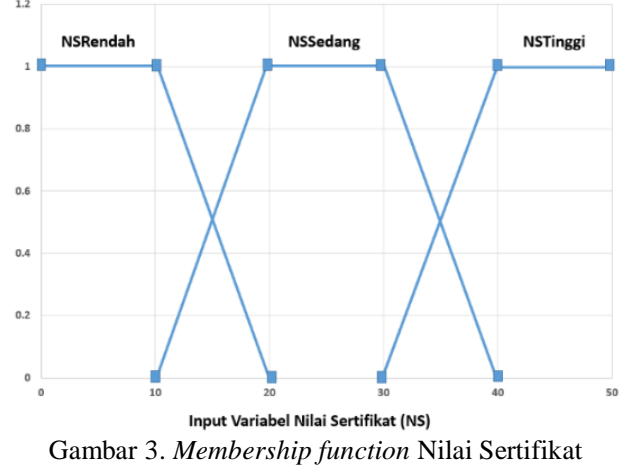

Status [x]: untuk variabel output status terdiri dari dua nilai linguistik, yakni Tidak Diterima dan Diterima, untuk fungsi keanggotaan (membership function) dirumuskan sebagai berikut:

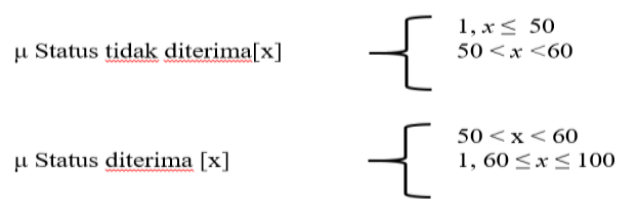

Membership function untuk status ditunjukkan pada Gambar 4. 


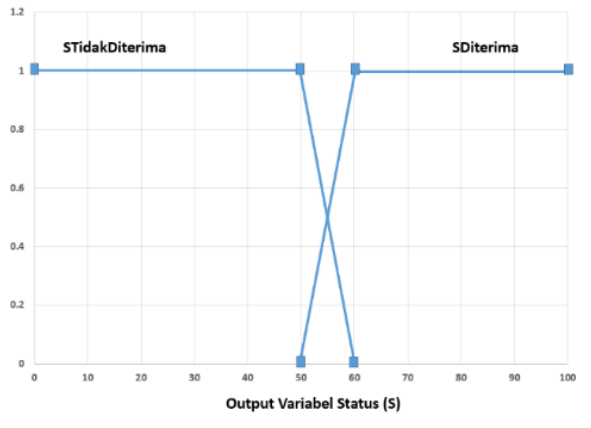

Gambar 4. Membership function Status

Langkah 2: Inference engine dalam menentukan keputusan status tidak diterima atau diterima. Didapatkan 27 Inference engine yang tersaji pada Tabel 2 .

Tabel 2. Inference Engine

\begin{tabular}{|c|c|}
\hline Rule & $\begin{array}{l}\text { Pernyataan } \\
\end{array}$ \\
\hline [R1] & $\begin{array}{l}\text { IF Nilai Wawancara is rendah AND Nilai Kuesioner is } \\
\text { rendah AND Nilai Sertifikat is rendah THEN tidak } \\
\text { diterima }\end{array}$ \\
\hline [R2] & $\begin{array}{l}\text { IF Nilai Wawancara is rendah AND Nilai Kuesioner is } \\
\text { rendah AND Nilai Sertifikat is tinggi THEN tidak } \\
\text { diterima }\end{array}$ \\
\hline [R3] & $\begin{array}{l}\text { IF Nilai Wawancara is rendah AND Nilai Kuesioner is } \\
\text { rendah AND Nilai Sertifikat is sedang THEN tidak } \\
\text { diterima }\end{array}$ \\
\hline [R4] & $\begin{array}{l}\text { IF Nilai Wawancara is rendah AND Nilai Kuesioner is } \\
\text { sedang AND Nilai Sertifikat is rendah THEN tidak } \\
\text { diterima }\end{array}$ \\
\hline [R5] & $\begin{array}{l}\text { IF Nilai Wawancara is rendah AND Nilai Kuesioner is } \\
\text { sedang AND Nilai Sertifikat is tinggi THEN tidak } \\
\text { diterima }\end{array}$ \\
\hline [R6] & $\begin{array}{l}\text { IF Nilai Wawancara is rendah AND Nilai Kuesioner is } \\
\text { sedang AND Nilai Sertifikat is sedang THEN tidak } \\
\text { diterima }\end{array}$ \\
\hline [R7] & $\begin{array}{l}\text { IF Nilai Wawancara is rendah AND Nilai Kuesioner is } \\
\text { tinggi AND Nilai Sertifikat is rendah THEN tidak } \\
\text { diterima }\end{array}$ \\
\hline [R8] & $\begin{array}{l}\text { IF Nilai Wawancara is rendah AND Nilai Kuesioner is } \\
\text { tinggi AND Nilai Sertifikat is tinggi THEN tidak } \\
\text { diterima }\end{array}$ \\
\hline [R9] & $\begin{array}{l}\text { IF Nilai Wawancara is rendah AND Nilai Kuesioner is } \\
\text { tinggi AND Nilai Sertifikat is sedang THEN tidak } \\
\text { diterima }\end{array}$ \\
\hline [R10] & $\begin{array}{l}\text { IF Nilai Wawancara is sedang AND Nilai Kuesioner is } \\
\text { tinggi AND Nilai Sertifikat is rendah THEN diterima }\end{array}$ \\
\hline [R11] & $\begin{array}{l}\text { IF Nilai Wawancara is sedang AND Nilai Kuesioner is } \\
\text { tinggi AND Nilai Sertifikat is tinggi THEN diterima }\end{array}$ \\
\hline [R12] & $\begin{array}{l}\text { IF Nilai Wawancara is sedang AND Nilai Kuesioner is } \\
\text { tinggi AND Nilai Sertifikat is sedang THEN diterima }\end{array}$ \\
\hline [R13] & $\begin{array}{l}\text { IF Nilai Wawancara is sedang AND Nilai Kuesioner is } \\
\text { sedang AND Nilai Sertifikat is rendah THEN tidak } \\
\text { diterima }\end{array}$ \\
\hline [R14] & $\begin{array}{l}\text { IF Nilai Wawancara is sedang AND Nilai Kuesioner is } \\
\text { sedang AND Nilai Sertifikat is tinggi THEN diterima }\end{array}$ \\
\hline [R15] & $\begin{array}{l}\text { IF Nilai Wawancara is sedang AND Nilai Kuesioner is } \\
\text { sedang AND Nilai Sertifikat is sedang THEN diterima }\end{array}$ \\
\hline [R16] & $\begin{array}{l}\text { IF Nilai Wawancara is sedang AND Nilai Kuesioner is } \\
\text { rendah AND Nilai Sertifikat is rendah THEN tidak } \\
\text { diterima }\end{array}$ \\
\hline [R17] & $\begin{array}{l}\text { IF Nilai Wawancara is sedang AND Nilai Kuesioner is } \\
\text { rendah AND Nilai Sertifikat is tinggi THEN tidak } \\
\text { diterima }\end{array}$ \\
\hline [R18] & $\begin{array}{l}\text { IF Nilai Wawancara is sedang AND Nilai Kuesioner is } \\
\text { rendah AND Nilai Sertifikat is sedang THEN diterima }\end{array}$ \\
\hline [R19] & $\begin{array}{l}\text { IF Nilai Wawancara is tinggi AND Nilai Kuesioner is } \\
\text { rendah AND Nilai Sertifikat is rendah THEN tidak } \\
\text { diterima }\end{array}$ \\
\hline
\end{tabular}

\begin{tabular}{cl}
\hline [R20] & $\begin{array}{l}\text { IF Nilai Wawancara is tinggi AND Nilai Kuesioner is } \\
\text { rendah AND Nilai Sertifikat is tinggi THEN tidak } \\
\text { diterima }\end{array}$ \\
\hline$[R 21]$ & $\begin{array}{l}\text { IF Nilai Wawancara is tinggi AND Nilai Kuesioner is } \\
\text { rendah AND Nilai Sertifikat is sedang THEN tidak } \\
\text { diterima }\end{array}$ \\
\hline$[R 22]$ & $\begin{array}{l}\text { IF Nilai Wawancara is tinggi AND Nilai Kuesioner is } \\
\text { sedang AND Nilai Sertifikat is rendah THEN tidak } \\
\text { diterima }\end{array}$ \\
\hline$[R 23]$ & $\begin{array}{l}\text { IF Nilai Wawancara is tinggi AND Nilai Kuesioner is } \\
\text { sedang AND Nilai Sertifikat is tinggi THEN diterima }\end{array}$ \\
\hline$[R 24]$ & $\begin{array}{l}\text { IF Nilai Wawancara is tinggi AND Nilai Kuesioner is } \\
\text { sedang AND Nilai Sertifikat is sedang THEN diterima }\end{array}$ \\
\hline$[R 25]$ & $\begin{array}{l}\text { IF Nilai Wawancara is tinggi AND Nilai Kuesioner is } \\
\text { tinggi AND Nilai Sertifikat is rendah THEN diterima }\end{array}$ \\
\hline$[R 26]$ & $\begin{array}{l}\text { IF Nilai Wawancara is tinggi AND Nilai Kuesioner is } \\
\text { tinggi AND Nilai Sertifikat is tinggi THEN diterima }\end{array}$ \\
\hline$[R 27]$ & $\begin{array}{l}\text { IF Nilai Wawancara is tinggi AND Nilai Kuesioner is } \\
\text { tinggi AND Nilai Sertifikat is sedang THEN diterima }\end{array}$
\end{tabular}

Langkah 3: Proses perhitungan $\alpha$-predikat, $z$, dan (a-predikat*z) ditunjukkan pada Tabel 3.

Tabel 3. Hasil Perhitungan

\begin{tabular}{|c|c|c|c|c|c|c|}
\hline $\begin{array}{c}\boldsymbol{\mu} \\
\mathbf{N W}\end{array}$ & $\begin{array}{c}\boldsymbol{\mu} \\
\mathbf{N K}\end{array}$ & $\underset{\mathbf{N S}}{\boldsymbol{\mu}}$ & Status & $\alpha$ & $\mathbf{z}$ & $\alpha^{*} \mathbf{z}$ \\
\hline 0 & 0 & 0 & Tidak diterima & 0 & 100 & 0 \\
\hline 0 & 0 & 1 & Tidak diterima & 0 & 100 & 0 \\
\hline 0 & 0 & 0,5 & Tidak diterima & 0 & 100 & 0 \\
\hline 0 & 0,5 & 0 & Tidak diterima & 0 & 100 & 0 \\
\hline 0 & 0,5 & 1 & Tidak diterima & 0 & 100 & 0 \\
\hline 0 & 0,5 & 0,5 & Tidak diterima & 0 & 100 & 0 \\
\hline 0 & 1 & 0 & Tidak diterima & 0 & 100 & 0 \\
\hline 0 & 1 & 1 & Tidak diterima & 0 & 100 & 0 \\
\hline 0 & 1 & 0,5 & Tidak diterima & 0 & 100 & 0 \\
\hline 0,5 & 1 & 0 & Diterima & 0 & 50 & 0 \\
\hline 0,5 & 1 & 1 & Diterima & 0,5 & 80 & 40 \\
\hline 0,5 & 1 & 0,5 & Diterima & 0,5 & 80 & 40 \\
\hline 0,5 & 0,5 & 0 & Tidak diterima & 0 & 100 & 0 \\
\hline 0,5 & 0,5 & 1 & Diterima & 0,5 & 80 & 40 \\
\hline 0,5 & 0,5 & 0,5 & Diterima & 0,5 & 80 & 40 \\
\hline 0,5 & 0 & 0 & Tidak diterima & 0 & 100 & 0 \\
\hline 0,5 & 0 & 1 & Tidak diterima & 0 & 100 & 0 \\
\hline 0,5 & 0 & 0,5 & Diterima & 0 & 50 & 0 \\
\hline 1 & 0 & 0 & Tidak diterima & 0 & 100 & 0 \\
\hline 1 & 0 & 1 & Tidak diterima & 0 & 100 & 0 \\
\hline 1 & 0 & 0,5 & Tidak diterima & 0 & 100 & 0 \\
\hline 1 & 0,5 & 0 & Tidak diterima & 0 & 100 & 0 \\
\hline 1 & 0,5 & 1 & Diterima & 0,5 & 80 & 40 \\
\hline 1 & 0,5 & 0,5 & Diterima & 0,5 & 80 & 40 \\
\hline 1 & 1 & 0 & Diterima & 0 & 50 & 0 \\
\hline 1 & 1 & 1 & Diterima & 1 & 110 & 110 \\
\hline 1 & 1 & 0,5 & Diterima & 0,5 & 80 & 40 \\
\hline \multicolumn{4}{|c|}{ Jumlah } & 4,5 & & 390 \\
\hline
\end{tabular}

Sesudah didapatkan perhitungan $\alpha$-predikat, $z$, dan (a-predikat*z), kemudian dilakukan perhitungan untuk menentukan kategori status pada Langkah 4.

Langkah 4: Proses defuzzifikasi dimana mencari nilai output berupa nilai crisp z. Dalam kasus ini menghitung status dengan langkah $z^{*}$ dihitung berdasarkan rules yang telah dibuat dan nilai $\alpha$ predikat yang didapat sesuai dengan persamaan (1) berikut:

Jumlah $\alpha$-predikat $=4,5$

Jumlah $\alpha$-predikat*z $=390$ 
$Z=\frac{\sum a-\text { predikat } * Z}{\sum a-\text { predikat }}$

$z=\frac{390}{4,5}=86,67$

Jadi nilai Z Status adalah 86,67 termasuk dalam kategori "Diterima".

\subsection{Perhitungan Sistem}

Perhitungan sistem ini berfungsi untuk mengetahui apakah sistem yang dibangun berjalan sesuai harapan dan secara otomatis status apa yang didapat oleh mahasiswa sebagai calon penghuni asrama, yaitu dengan menginputkan data mahasiswa, nilai wawancara, nilai kuesioner, dan nilai sertifikat pada form yang telah disajikan pada sistem secara otomatis ditunjukkan pada Gambar 5.

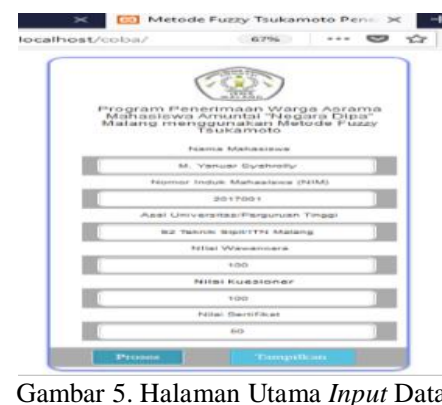

Sebagai contoh data, Nama Mahasiswa: M. Yanuar Syahrolly, Nomor Induk Mahasiswa (NIM): 2017xxxxxxxxx, Asal Universitas/Perguruan Tinggi: S2 Teknik Sipil/ITN Malang, Nilai Wawancara: 100, Nilai Kuesioner: 100, Nilai Sertifikat: 50. Selanjutnya klik tombol Proses, kemudian sistem melakukan proses perhitungan dan memperoleh output berupa kategori dari status yang akan didapat oleh mahasiswa sebagai calon penghuni asrama. Antara perhitungan manual dengan perhitungan yang dilakukan oleh sistem memperoleh output yang sama yaitu status diterima, namun untuk nilai z nya memiliki perbedaan.

\subsection{Pengujian Akurasi}

Untuk mengetahui performa maka dilakukan pengujian akurasi antara penilaian pakar, perhitungan Fuzzy Tsukamoto secara manual, dan perhitungan Fuzzy Tsukamoto secara otomatis menggunakan sistem yang telah dibangun. Prosedur pengujiannya adalah membandingkan antara hasil penilaian pakar, hasil perhitungan Fuzzy Tsukamoto secara manual, dan hasil perhitungan Fuzzy Tsukamoto secara otomatis menggunakan sistem yang telah dibangun tersaji pada Tabel 4 .

\begin{tabular}{|c|c|c|c|c|c|c|c|c|c|c|c|}
\hline No. & $\begin{array}{l}\text { Inisial } \\
\text { Nama }\end{array}$ & NW & NK & NS & $\begin{array}{c}\text { Penilaian } \\
\text { Fuzzy } \\
\text { Tsukamoto } \\
\text { Manual }\end{array}$ & Status & $\begin{array}{c}\text { Penilaian } \\
\text { Pakar }\end{array}$ & Status & $\begin{array}{c}\text { Penilaian } \\
\text { Fuzzy } \\
\text { Tsukamoto } \\
\text { Otomatis }\end{array}$ & Status & $\begin{array}{c}\text { Hasil } \\
\text { Akurasi }\end{array}$ \\
\hline 1 & $\mathrm{AF}$ & 90 & 90 & 30 & 92,08 & Diterima & 70 & Diterima & 100 & Diterima & 1 \\
\hline 2 & $\mathrm{AH}$ & 90 & 90 & 40 & 62,50 & Diterima & 73,33 & Diterima & 100 & Diterima & 1 \\
\hline 3 & FB & 90 & 10 & 50 & 93,79 & Diterima & 50 & $\begin{array}{c}\text { Tidak } \\
\text { Diterima }\end{array}$ & 0 & $\begin{array}{c}\text { Tidak } \\
\text { Diterima }\end{array}$ & 0 \\
\hline 4 & HRB & 50 & 35 & 40 & 50 & $\begin{array}{c}\text { Tidak } \\
\text { Diterima }\end{array}$ & 41,67 & $\begin{array}{c}\text { Tidak } \\
\text { Diterima }\end{array}$ & 0 & $\begin{array}{c}\text { Tidak } \\
\text { Diterima }\end{array}$ & 1 \\
\hline 5 & HP & 80 & 90 & 40 & 127,50 & Diterima & 70 & Diterima & 100 & Diterima & 1 \\
\hline 6 & $\mathrm{KJ}$ & 55 & 40 & 50 & 95,90 & Diterima & 48,33 & $\begin{array}{c}\text { Tidak } \\
\text { Diterima }\end{array}$ & 0 & $\begin{array}{c}\text { Tidak } \\
\text { Diterima }\end{array}$ & 0 \\
\hline 7 & MAS & 80 & 20 & 45 & 93,54 & Diterima & 48,33 & $\begin{array}{c}\text { Tidak } \\
\text { Diterima }\end{array}$ & 0 & $\begin{array}{c}\text { Tidak } \\
\text { Diterima }\end{array}$ & 0 \\
\hline 8 & MRF & 70 & 25 & 50 & 94,86 & Diterima & 48,33 & $\begin{array}{c}\text { Tidak } \\
\text { Diterima }\end{array}$ & 0 & $\begin{array}{c}\text { Tidak } \\
\text { Diterima }\end{array}$ & 0 \\
\hline 9 & MYS & 100 & 100 & 50 & 86,67 & Diterima & 83,33 & Diterima & 100 & Diterima & 1 \\
\hline 10 & $\mathrm{Ma}$ & 60 & 50 & 40 & 94,03 & Diterima & 50 & $\begin{array}{c}\text { Tidak } \\
\text { Diterima }\end{array}$ & 0 & $\begin{array}{c}\text { Tidak } \\
\text { Diterima }\end{array}$ & 0 \\
\hline 11 & MA & 55 & 60 & 25 & 43 & $\begin{array}{c}\text { Tidak } \\
\text { Diterima }\end{array}$ & 46,67 & $\begin{array}{c}\text { Tidak } \\
\text { Diterima }\end{array}$ & 100 & Diterima & 1 \\
\hline 12 & MI & 60 & 20 & 30 & 54 & $\begin{array}{c}\text { Tidak } \\
\text { Diterima }\end{array}$ & 36,67 & $\begin{array}{c}\text { Tidak } \\
\text { Diterima }\end{array}$ & 0 & $\begin{array}{c}\text { Tidak } \\
\text { Diterima }\end{array}$ & 1 \\
\hline 13 & MP & 80 & 60 & 30 & 90,94 & Diterima & 56,67 & $\begin{array}{c}\text { Tidak } \\
\text { Diterima }\end{array}$ & 100 & Diterima & 0 \\
\hline 14 & MYR & 75 & 60 & 50 & 100,65 & Diterima & 61,67 & Diterima & 75 & Diterima & 1 \\
\hline 15 & MY & 20 & 20 & 20 & 30,67 & $\begin{array}{c}\text { Tidak } \\
\text { Diterima }\end{array}$ & 60 & $\begin{array}{c}\text { Tidak } \\
\text { Diterima }\end{array}$ & 0 & $\begin{array}{c}\text { Tidak } \\
\text { Diterima }\end{array}$ & 1 \\
\hline 16 & PPS & 75 & 70 & 30 & 91,58 & Diterima & 58,33 & $\begin{array}{c}\text { Tidak } \\
\text { Diterima }\end{array}$ & 75 & Diterima & 0 \\
\hline 17 & $\mathrm{RH}$ & 80 & 85 & 35 & 95,37 & Diterima & 66,67 & Diterima & 75 & Diterima & 1 \\
\hline 18 & $\mathrm{RF}$ & 30 & 20 & 40 & 50 & $\begin{array}{c}\text { Tidak } \\
\text { Diterima }\end{array}$ & 30 & $\begin{array}{c}\text { Tidak } \\
\text { Diterima }\end{array}$ & 0 & $\begin{array}{c}\text { Tidak } \\
\text { Diterima }\end{array}$ & 1 \\
\hline 19 & RNR & 85 & 85 & 40 & 80 & Diterima & 70 & Diterima & 75 & Diterima & 1 \\
\hline
\end{tabular}


Berdasarkan Tabel 4 telah dilakukan pengujian akurasi dengan data berjumlah 19 orang dengan masing-masing nilai inputan. Untuk mengetahui hasil dari pengujian nilai akurasi maka digunakan persamaan (2) berikut:

$N A=\frac{\sum(\text { Data Akurat })}{\sum(\text { Seluruh Data })} \times 100 \%$

$N A=\frac{12}{19} \times 100 \%=63,15 \%$

Akurasi dengan menggunakan Metode Fuzzy Tsukamoto berdasarkan 19 data dengan membandingkan antara hasil penilaian pakar, hasil perhitungan Fuzzy Tsukamoto secara manual, dan hasil perhitungan Fuzzy Tsukamoto secara otomatis menggunakan sistem yang terprogram, telah diuji mempunyai tingkat akurasi keberhasilan sebesar $63,15 \%$ dengan predikat cukup.

\section{KESIMPULAN}

Kesimpulan dari penelitian ini yaitu: (1) Cara kerja Metode Fuzzy Tsukamoto memiliki tiga bagian yaitu: fuzzifikasi, inferensi fuzzy, dan defuzzifikasi, (2) Implementasi Metode Fuzzy Tsukamoto dapat menghitung penentuan penerimaan penghuni asrama mahasiswa pada studi kasus asrama mahasiswa putera "Negara Dipa Amuntai Malang" berdasarkan 19 data dengan membandingkan antara hasil penilaian pakar, hasil perhitungan Fuzzy Tsukamoto secara manual, dan hasil perhitungan Fuzzy Tsukamoto secara otomatis menggunakan sistem yang terprogram, telah diuji mempunyai tingkat akurasi keberhasilan sebesar 63,15\% dengan predikat cukup. Pekerjaan masa depan yang diharapkan adalah peningkatan hasil akurasi, penambahan jumlah data uji, dan kombinasi antar metode yang ada dalam kecerdasan komputasional.

\section{DAFTAR PUSTAKA}

AFIF, M., DKK. 2017. Prediksi Jumlah Produksi Tas pada Home Industri Body Star Kudu Menggunakan Fuzzy Tsukamoto. Jurnal Ilmiah SISFOTENIKA. Vol. 7, No. 2, Juli 2017, hlm. 119-130.

ANGIN, M. I. P., DKK. 2017. Implementation of Fuzzy Tsukamoto Algorithm in Determining Work Feasibility. IOSR Journal of Computer Engineering (IOSRJCE) e-ISSN: 2278-0661,p-ISSN: 22788727, Volume 19, Issue 4, Ver. IV. (Jul.Aug. 2017), PP 52-55.

ARMANDA, R. S., MAHMUDY, W. F. DKK. 2016. Penerapan Algoritma Genetika untuk Penentuan Batasan Fungsi Keanggotaan Fuzzy Tsukamoto pada Kasus Peramalan Permintaan Barang. Jurnal Teknologi Informasi dan Ilmu Komputer (JTIIK). Vol. 3, No. 3, September 2016, hlm. 169-
173. Malang: Fakultas Ilmu Komputer Universitas Brawijaya.

ARIFIN, M., ASFANI, K. \& HANDAYANI, A. N. 2016. Akurasi Perhitungan dalam Penentuan Beasiswa dengan Metode Fuzzy Tsukamoto Berbasis Web. Jurnal Maklumatika. Volume 3, Nomor 1, Juli 2016.

BACHTIAR, F. A. DKK. 2015. Student Assessment Based on Affective Factors Using Fuzzy Membership Function and Fuzzy Rules. International Journal of Affective Engineering. Vol. 15 No. 2 (Special Issue) pp. 101-108. doi: 10.5057/ijae.IJAE-D-1500037. Conference: International Symposium on Affective Science and Engineering (ISASE). Tokyo: Japan.

BUNGA, A. \& MAHMUDY, W. F. 2014. Penentuan Kategori Beasiswa Mahasiswa menggunakan Metode Fuzzy Tsukamoto.

FUZZIFIKASI, T. 2013. Fuzzy Tsukamoto. Hlm. 16.

GERHANA, Y. A. DKK. 2018. Decision Support System for Football Player's Position with Tsukamoto Fuzzy Inference System. MATEC Web of Conferences. https://doi.org/10.1051/matecconf/2018197 03014. AASEC.

HADI, H. N. \& MAHMUDY, W. F. 2015. Penilaian Prestasi Kinerja Pegawai Menggunakan Fuzzy Tsukamoto. Jurnal Teknologi Informasi dan Ilmu Komputer (JTIIK). Vol. 2, No. 1, April 2015, hlm. 41-48. Malang: Fakultas Ilmu Komputer Universitas Brawijaya.

INDRIANA, A. \& MAHMUDY, W. F. (2014). Penerapan Logika Fuzzy Metode Tsukamoto untuk Menentukan Kualitas Hotel.

IRMAYANTI, H. 2018. Employee Recruitment with Fuzzy Tsukamoto Algorithm. IOP Publishing. IOP Conf. Series: Materials Science and Engineering. doi:10.1088/1757-899X/407/1/012162. INCITEST UNIKOM. Bandung.

JUMADI, DKK. 2018. Design of Expert System for Train Operational Feasibility with Tsukamoto Fuzzy Inference System. MATEC Web of Conferences. https://doi.org/10.1051/matecconf/2018197 03015. AASEC.

KHAN, R. D. \& WULANDARI, R. 2016. Studi Komparasi Fasilitas dan Satndar Asrama di Indonesia: Studi Kasus 5 Universitas. Jurnal Desain Interior dan Desain Produk (IDEALOG). Vol. 1 No. 2, Agustus 2016, ISSN 2477-0566. 
KRUSE, RUDOLF., BORGELT, CHRISTIAN. \& STEINBRECHER, MATTHIAS. 2013.

Computational Intelligence: A Methodological Introduction. London: Springer.

KURNIANINGTYAS, D., MAHMUDY, W. F. \& WIDODO, A. W. 2017. Optimasi Derajat Keanggotaan Fuzzy Tsukamoto Menggunakan Algoritma Genetika untuk Diagnosis Penyakit Sapi Potong. Jurnal Teknologi Informasi dan Ilmu Komputer (JTIIK). Vol. 4, No. 1, Maret 2017, hlm. 818. Malang: Fakultas Ilmu Komputer Universitas Brawijaya.

MULYANTO, A. \& HARIS, A. 2016. Penerapan Metode Fuzzy Tsukamoto Untuk Menentukan Jumlah Jam Overtime Pada Produksi Barang di PT Asahi Best Base Indonesia (ABBI) Bekasi. Jurnal Informatika SIMANTIK. Vol.1, No.1 September 2016.

PAREWE, A. M. A. K. \& MAHMUDY, W. F. 2016. Seleksi Calon Karyawan Menggunakan Metode Fuzzy Tsukamoto. Seminar Nasional Teknologi Informasi dan Komunikasi (SENTIKA). Yogyakarta.

ROHAYANI, H. 2015. Fuzzy Inference System Dengan Metode Tsukamoto Sebagai Penunjang Keputusan Produksi (Studi Kasus : PT. Talkindo Selaksa Anugrah). Jurnal Sistem Informasi (JSI).Vol. 7, No. 1, April 2015, ISSN Print : 2085-1588, ISSN Online : 2355-4614.

QUR'ANIA, A. \& VERANANDA, D. I. 2018. Tsukamoto Fuzzy Implementation to Identify The Pond Water Quality of KOI. IOP Publishing. IOP Conf. Series: Materials Science and Engineering. doi:10.1088/1757-899X/166/1/012018. IORA.

Website Resmi Pemerintah Kabupaten Hulu Sungai Utara. Tersedia di: http://www.hulusungaiutarakab.go.id/ [Diakses 16 November 2017]. 
Halaman ini sengaja dikosongkan 